\title{
Manipulation and Propaganda in the Russian Media:The Case of the Vriemia News Programme (2017-2019)
}

Anna Llanos-Antczak ${ }^{1}$ and Zdzisław Śliwa²

Information is a powerful tool used in any society and by any nation to create excepted perception of reality. Russian information operations have always been a very interesting example of using various media to manipulate international and domestic opinion in support of national (government) objectives. The situation has not changed in the contemporary information environment based on the nation's experiences and skilful utilization of emerging tools and technologies. Those capabilities are used pragmatically by Kremlin-controlled media to shape the future among younger people. In this respect, the paper is based on research conducted in selected Moscow and Saint Petersburg universities, responsible for educating future generations. The research is based on young adults' perception of the information provided by Channel One (Russian: Первый канал). This is the most influential and popular television channel controlled by the current government; therefore, it plays a significant role in spreading propaganda to shape the perception of the realm by domestic and foreign audiences alike. The authors conducted research in the years 2017-2019, employing the survey method to find out what is the effect of television-based propaganda type of information to manipulate the recipients. The research revealed that, although the Russian media strongly influences the study group, the respondents recognize the utilization of propaganda, which is founded on a one-sided narrative, and they are not easily manipulated. Moreover, the results presented that there is an interdependence between the favourable opinions about Channel One's Vriemia news coverage and vulnerability to manipulation and propaganda techniques.

KEY WORDS: $\quad$ Vriemia, newscast, news programme, manipulation in mass media, propaganda.

JEL Classification: F59.

University of Economics and Human Sciences in Warsaw, Poland

Baltic Defence College, Tartu, Estonia ${ }^{2}$

\section{Introduction}

Russia's aggressive utilization of media has been recognized as a substantial threat to the democratic nations based on the application of propaganda to manipulate selected nations and targeted groups. The European Parliament acknowledged a range of sophisticated attacks in the period of 2019-2020, focused on particular audiences, which applied

Correspondence concerning this article should be addressed to:

Anna Llanos-Antczak, University of Economics and Human Sciences in Warsaw, Okopowa 59, Warszawa 01-043 Poland

E-mail:a.a.antczak@vizja.pl intensity by pragmatically using the unfolding events (Bayer et al., 2021). This is a real challenge, considering the recent "growing concern not only about the ongoing efforts of Russian influence campaigners but also the uptake by other groups (or 'domestic actors') of the so-called 'Russian playbook'” (Rogers, Niederer, 2020, p. 28). This is connected with the implementation of new methods, technologies and computational propaganda (Bradshaw \& Howard, 2019) to manipulate not only external audiences but also Russian society. The challenge is that although Russian propaganda can reach the Western 
nations, it is not easy to reach Russian society with counterpropaganda. Consequently, it is necessary to study how Russian society perceives the Kremlincontrolled narrative to use this knowledge to support the progression toward democratic values.

Based on Channel One's Vriemia news show, the current study investigates the impact of Russian media on young adults aged 18 to 34 . This enables researchers to investigate young adults' perceptions of their environment, particularly the impact of the media on their perceptions of Russia, the West, and their own politics and society. Generation $\mathrm{Z}$ and Millenials are of particular importance, as "generations are a lens through which to understand societal change" (Dimock, 2019). The research conducted between 2017 - 2019 in selected Moscow and Saint Petersburg universities was focused on those people who will and already are impacting the future of Russia; therefore, understanding their point of view and susceptibility to propaganda is of great importance. This is clearly understood by the current Russian leadership; consequently, the highly influential and popular Channel One is used purposefully to shape the minds of future decisionmakers, leaders, academics, businesspersons, etc. In general, those who will take key positions within all the domains of statehood. In this context, the advantage of this research is its focus, as most studies are centred on the impact of the various tools used by Russian media on the Western societies. In this respect, the study contributes to the debate about the utilization of information operations toward domestic audiences concentrating on carefully selected groups. The study period was carefully selected, as the reactions and emotions calmed down after the war in Ukraine and the annexation of Crimea. The paper follows a logical construction. The selected literature covering the area of research is considered, followed by the outline of methodology to elaborate methods and tools applied in the research. An overview of Channel One is provided, the state television's role as an actor of information operations is presented. The last sections involve key analytical constituents of the article presenting focus groups, findings, and outcomes of the research. They include figures to visualize the results.

\section{Literature Review}

Russian media and its propagandistic utilization to support the current government has been the focus of many publications trying to analyse its impact on external and internal audiences. The reason for that is that Russian propaganda is a very aggressive and dangerous tool used without any limits to forward purposefully developed key messages and narratives. Strovsky and Schleifer (2020) conducted Russian media-related research, regarding the Syrian Civil War. The research focused on exploring the narratives of the three Russian newspapers: Rossiyskaya Gazeta, Kommersant, and Komsomolskaya Pravda between 2001 and 2015, with some insights into the period until 2018. The study provided the reasons for Russian interest and connection with the Middle East and therefore, proving that the involvement in the conflict was a logical consequence (the media's task was to present a positive image of Russian involvement there). One of the interesting conclusions of this research was the statement that "under $\mathrm{Pu}$ tin's rule, the media still needed paternalistic support from the authorities, which led to the development of habitual clientelism" (Strovsky \& Schleifer, 2020, p. 8). Therefore, the studied newspapers published news almost every day, developing some 1500 items each within the studied period, focusing on painting a positive picture of President Assad and Russia but avoiding such difficult topics as the socio-political situation in Syria. Only small differences between narratives were recognized: "evaluating the nature of the Syrian opposition, Rossiyskaya Gazeta has used more moderate and less emotional language, compared to Komsomolskaya Pravda" (Strovsky \& Schleifer, 2020, p. 19). The one-sided storyline was perceived by the researchers as evidence of "the politicized approach of the Russian papers" leading to the provision of the false description of the reality of the Syrian Civil War. Such newspapers are recognized as ideologically biased, presenting "a clear confirmation of journalistic strong dependence on the authorities in contemporary Russia" making media "a mouthpiece of state interests", which uses manipulative techniques in a negatively perceived creative way (Strovsky \& Schleifer, 2020, p. 22-23). This research backs up the claim that there is a unified approach of the Russian government to use the media to influence a specific audience with a narrative in support of the authorities. 
The comprehensive study of Russian disinformation, which relates to the research within this paper, was conducted by Thomas Kent (2020). He recognized that "the characteristics of the information conflict with Russia are far different from the wars that major Western democracies have known" (Kent, 2020, p. 3). The author asserts that the word war is crucial for Russian disinformation operations; to face it the West nations are developing ways and means allowing them to conduct coherent counteractions. Therefore, he is putting an accent on this aspect, trying to answer the question of who should be in the lead and how to make information war effective against very well targeted and flexible Russian information operations. The author also discusses the goals of messaging, messages' themes, and message senders, assessing their effectiveness. Kent, however, recognizes the challenge of reaching the population but also the ability "to create content interesting enough that Russians will make an effort to get it" (Kent, 2020, p. 215). The practical value of the book is the provision of recommendations within a few possible strategies to achieve desired end state of countering Russian disinformation. Another advantage is the presentation of a range of publications used for the study allowing the readers to conduct their research within this intriguing area of contemporary information operations.

A similar conceptual study was conducted by Ramsay and Robertshaw (2019). The researchers analysed "151,809 online articles published by UK national news outlets and 11,819 articles on the English-language sites of RT and Sputnik across two four-week samples from May-June 2017 and March 2018" (Ramsay \& Robertshaw, 2019, p. 16). The creation of the Steno-Similar tool allowed to compare both national databases and assess to what extent stories created by one country are reproduced by the other one. It included the Skripal case, handling of NATO topics, portraying the West with specific attention to applying the methodology on Russian-language news in Russia and Ukraine (Ramsay \& Robertshaw, 2019, pp. 93-98). Recognizing churnalism as information warfare, the study recommends further research on how "the Russian state uses external journalism as a tool for influencing its domestic audiences as well as audiences internationally" (Ramsay \& Robertshaw, 2019, p. 102).
Another interesting and complex assessment of the Russian application of media in terms of supporting national objectives was published by Mölder et al. (2021). The book, exploiting interdisciplinary and intertheoretical and methodological approaches, covers a range of arguments on the role of information manipulation in the contemporary security environment. It also provides a very solid analysis that allows understanding why the Russian Federation is believed to have taken on the role of an advanced player in global knowledge warfare.

Berzina (2018) analysed Russian television in Latvia and its impact on Russian speaking population. The research was focused on the relationship between political trust and media from 2007 to 2017 examining the First Baltic Channel (PBK), NTV Mir Baltic (NTV), and RTR Planeta Baltija (RTR). She concluded that "Russia uses a variety of information tools to achieve its political and military goals. Russian stateowned media is one of the important elements in this toolbox" (Berzina, 2018, p. 3). The research confirmed the existence of the impact of the media on the political trust of discussed part of the society toward government and parliament. It significantly decreased between 2007 and 2013 (to 15\%), to raise from 2014 until 2017 (up to respectively 28\% and 20\%). This could be related to matters of security, especially the annexation of Crimea and the war in Ukraine. The Russian-speaking population's interest in watching Russian television slightly decreased, which impacted the political trust of Latvian authorities. The researcher concluded that "Russia's information influence activities affect political trust indirectly" and it is specifically referred also to domestic factors by underpinning the current Russian government (Berzina, 2018, p. 8). Although locally or regionally Russian television's impact is still important, according to the Economist, for example, the Russian Today TV channel with its budget of $300 \mathrm{mln}$ USD was ineffective when managing the Kremlin-directed campaign to undermine faith in the US Government. It was recognized as "toxic, but not viral" (The Economist, 2017). A regional perspective on Russian propaganda has also been researched by Andriukaitis (2020). The remarkable benefit of this publication is the analysis of case studies related to the presence of the NATO enhanced Forward Presence troops from Germany in 
Lithuania and fake news used by the Russian narrative to show the Alliance soldiers in a negative way. It is based on information used in "large quantities and disseminated through the variety of channels" with adjusting messages toward specific audiences both in Russia, Lithuania, and in the West (Andriukaitis, 2020 , p. 5). According to the author, an important factor is the development of informational resilience based on proactive national institutions, technological means, and education of whole societies.

Researchers of the RAND Corporation developed a study focused specifically on Russian social media propaganda impact on Eastern European countries using a synchronized mix of media (Helmus et al., 2018). This comprehensive study utilizes the quantitative analysis of social media data toward examining the impact on both the near abroad - former Soviet republics and farther abroad - Western and democratic institutions. The advantage of the report was the identification of U.S., European Union (EU), and NATO endeavours to counter Russia's influence. The report provides an interesting database and source of information for further studies including relevant data and references supporting its credibility. It also includes an overview of five key and overarching suggestions for improving the Western response to Russia's information activities against its neighbours (Helmus et al., 2018, p. 75). As an outcome of their research, the authors propose tools and ways of how to counter Russian propaganda towards near abroad and farther abroad in a coherent way. They suggest the usage of keywords and resilience as an alternative to Russian propaganda as well as to enhance own stories and to introduce an analytical approach to examine ways and means exploited by the Russian media.

An interesting joint study was conducted by the NATO Strategic Communication Centre of Excellence (NATO STRATCOM COE) and King's College London, focusing on fake news. It also analysed the Kremlin's perspective of using disinformation "to confuse rather than convince, to divide rather than provide an alternative point of view" (Averin, 2018, p. 59). The author discusses the Russian tradition of disinformation and replacing the idea of active measures with a more influential method to conduct information warfare called reflexive control developed by Lefebvre. It is linked with analysing troll factories to "penetrate Western public", and media such as Sputnik, RT, and Channel 1 to impact the "majority of Russians, both domestically and internationally" (Averin, 2018, p. 65). Moreover, Kovaleva (2018) provides an overview of Russian media space including the role of legal instruments to control it, even though she claims that the Kremlin "has not been able to establish complete control over Russian information space" (Kovaleva, 2018, p. 162).

An interesting study was conducted by Karlsen (2019) who analysed the 2014-2018 period focusing on Russian political influence activities toward the West. He assumed that the responsibility for covert influence activities is strongly connected with the Russian intelligence services, which are operating abroad. Namely, the Foreign Intelligence Service (SVR), the Main Intelligence Directorate (GRU) of the General Staff, and the Federal Security Service (FSB). In this respect, the paper is based on "about 40 annual reports from 15 intelligence and security services in 11 Western countries" (Karlsen, 2019, pp. 2-3), including Baltic region nations. The study includes specific focus areas exploited by the services mentioned above by which "Russia is targeting the West through a divide and rule approach, and is using media, social media, minorities, refugees, extremists, human intelligence, cyber operations, energy, business, corruption, allies, front organizations, history, and military force for its political influence activities" (Karlsen, 2019, pp. 12-13). The report is a solid review useful for a specific audience, but also any person interested in Russian political influence activities. Another report by Kuzichkin and Hanley (2021) delivers a very comprehensive overview of the political, financial, and legislative mechanisms to fully control media in Russia to influence the domestic audience and to shape the Western nations. The research is based on the study of the news agencies, radio stations, TV stations owned by Holdings and Owner-Controlled TV channels. They strongly focus on the role of media in consolidating power by the current Russian government.

The media coverage of utilizing information by Russian media is noticeable and it is done by think tanks, national research institutes, and individual experts dealing with the matter. The main focus is mainly on analysing specific TV channels, newspapers and social media both in a regional and global context. It 
is providing a lot of data allowing to conduct comparative studies, which is done in special reports as presented by, for example, RAND or NATO STRATCOM COE. Nevertheless, in some cases, it is based on secondary research limiting the uniqueness of studies. Some papers are rather general in essence causing an issue to assess the quality of the information and to draw reliable conclusions; however, many are contributing to debate about information as a tool of warfare or influence. Nevertheless, there are not many studies that deal with the way the information presented by Russian media is perceived by internal Russian audiences. Therefore, the novelty of the research is a contribution to such a specific domain, especially as it is focusing on the younger generation represented by the students at selected universities in Moscow and Saint Petersburg. The advantage is that is based on primary research conducted during a carefully selected period.

\section{Research Methodology}

The research is based on a survey method and was conducted in the years 2017-2019 in chosen universities in Russia (in Moscow and Saint Petersburg). The research was conducted to investigate the influence of news programmes (Vriemia in particular) on the degree of manipulation of society (conclusions were drawn based on the opinions presented by the respondents). The main aim of the research was to find out to what extent the propaganda techniques used in television transmissions of news programmes (Vriemia in this case) affect its recipients and to assess the attitude of people (viewers) towards the researched news programme as a means of receiving socio-political information. In order to obtain this goal, the following research questions were posed:

- To what extent does age, gender, education, and financial situation influence attitudes towards the contents of the Vriemia programme?

- How does the frequency of watching TV, Vriemia in particular, influence the opinions of the respondents about the programme itself and its content?

- To what extent does the frequency of watching TV, Vriemia in particular, affect the level to which a person succumbs to manipulation?

- To what extent do the types of opinions on Vri- emia influence the vulnerability to manipulation?

In order to achieve the goal of the research and to answer the above questions, some initial hypotheses were formulated to be verified with the analysis of the research results: Russian political marketing uses various techniques which are an important part of the media coverage. News is produced with the application of various political marketing and manipulation techniques, and consequently, it can manipulate the audience's opinions and attitudes. It is assumed that the more educated and better financially situated the respondents are, the more objective their perception of a programme's contents. This greater objectivity or even criticism should result in less vulnerability to manipulation. Additionally, the more often people watch TV, Vriemia in particular, the more vulnerable they are to manipulation and the less objectively they assess the programme. Those respondents who are critical of the programme's content are less vulnerable to manipulation and refuse to watch Vriemia frequently.

The survey was conducted by means of a questionnaire which was composed of ten questions (excluding personal data) and was divided into separate parts. The first one concerns not only the viewership of the TV programmes and the extent to which they treat the news presented as a source of information about current world events but also the attitudes of the audience to given TV stations and the news programmes they deliver, including the perception of the Channel One in comparison to other TV stations. The second part concerns the evaluation of the Vriemia programme and its characteristics. The above-stated questions were aimed at examining the respondents' opinions on the features of the message and the topics covered by the Vriemia programme (the respondents were to mark the statements which in their opinion were true). The statements were selected in such a way that the respondents could express their views on the following areas: the characteristics of the message (its objectivity), the topics discussed (the president, national and international affairs, officials, ordinary people's affairs, violence, religion, etc.) and the programme's function (e.g., who the message is intended for and whether it has educational features). Another aspect concerned the emotions that the programme could potentially arouse in 
the viewer while watching. The following emotions were selected to be included in the questionnaire in response to the techniques used by the broadcasters of the news: fear, pride in one's country/nation (granfalloon), hatred, indignation, and a sense of joy/happiness.

In order to analyse the obtained results and verify the adopted hypotheses, a number of specialised statistical tests were used, taking 0.05 as the threshold value. The following tests were applied:

- Pearson's chi-squared test for independence - to check for dependencies between variables;

- Likelihood-ratio test - to determine the goodness-of-fit between two models, one nested within the other;

- Student's t-test - to determine if two sets of data are significantly different from each other (normal distribution);

- ANOVA (analysis of variance) - to analyse the differences among group means in a sample;

- Gabriel post-hoc test (Gabriel's Pairwise Comparisons Test) - to determine dependencies/differences between given groups (pairs).

\section{Characteristics of Channel One Broadcasting the Vriemia News Programme}

The open joint-stock company Channel One is the largest state television station of the Russian Federation. From its inception in 1995 till 2002, the station was called the ORT or Russian Public Television. Channel One was created to replace the Ostankino Channel, which had started functioning after the liquidation of the First Programme of the Central Television of the USSR (Antczak \& Plashkina, 2017). At present, Channel One is a hybrid station - (with its headquarters in Moscow in the Ostankino television center (tower) - combining state and private capital. $51 \%$ of the shares of the Channel One station belong to the government of the Russian Federation, the remaining $49 \%$ is divided between two other entities. 38.9\% of the first tranche of the shares is owned by the Federal Agency for State Property Management of Russia; 9.1\% by Russian TASS Press Agency (also known as ITAR-TASS), which is directly administered by the Government of the Russian Federation; the remaining $3 \%$ of shares belong to the Ostankino Television Tech- nical Center, which is, in turn, subordinated to the aforementioned State Property Management Agency and the Federal Agency for Press and Mass Communication. The structure of the remaining shares (49\%) is not transparent and the information available on this matter comes mainly from journalist investigations (Sobolev, 2016; Glebko, 2013; Sagdiyev, Boleckaya 2010; Shcherakova, 2005). 24\% of the shares belongs to the company named ORT-BK, owned by Roman Abramovich, who manages it through companies registered in Cyprus (these shares were purchased in 2001 from Boris Bieriezovski). 25\% are owned (also indirectly) by the National Media Group, which was created in 2008 by three influential Russian companies: Severstal, operating in the steel and mining industry, Surgutneftegaz, of the gas and oil sector and the Rossiya Bank. The owner of Severstal is Alexei Mordashov, an entrepreneur whose activity began when Vladimir Putin came into power (Lukyanova, 2001) and who belongs to the closest environment of the president. Surgutneftegaz is a most enigmatic company, whose exact ownership structure is unknown. The Rossiya Bank was established in 1991 to replace the bank previously run by the Leningrad Regional Committee of the Communist Party of the Soviet Union. After the announcement of the ban on the continuation of the party's activities, the former mayor of St. Petersburg, Anatoly Sobchak, ordered his deputy, Vladimir Putin, to find new owners for the bank. These were Yuriy Kovalchuk and Vladimir Yakunin from the Saint Petersburg Joint Enterprises Association, supervised by Putin (Shcherakova, 2005). It is believed that Yuri Kovalchuk, who was subject to US sanctions in 2014, is one of Putin's closest associates who, together with other people close to Putin, founded the famous Oziero co-operative in the Leningrad Oblast (Łabuszewska, 2015). Consequently, it can be concluded that the ownership structure of the Channel One station clearly shows that all entities holding shares in the company are connected to the Kremlin, and therefore most likely represent its interests.

The Vriemia programme of Channel One was selected for analysis primarily because of its position as the most important (leading), opinion-forming station in the country, it has the largest audience reach in the Russian Federation (98.8\% of the population). It is also the most-watched and cited station in Russia 
of the 6 most viewed stations (Rossiya 1, NTV, TNT, STS, Channel Five, and REN TV) and the so-called Big Three, namely, the three most watched stations: Channel One, Rossiya 1, and NTV (Vartanova, 2014; 2016).

\section{Description of the Focus Group and Basic Research Findings}

The research was conducted among 150 persons, but 16 questionnaires were not filled in in a sufficient manner to include them into the research analysis, leaving 134 respondents (72 women and $61 \mathrm{men}$ ), from four universities in Moscow and Saint Petersburg. Most respondents were aged between 18 and 34 (98\%). Thus, the focus group was mainly represented by young people who were either students or administrative or academic staff of the universities. Most of the respondents possess higher education (bachelor's degree) or are during their bachelor or master studies (76\%). The financial situation of the respondents was generally stable, but not necessarily satisfactory, with $53 \%$ of the respondents declaring that they had enough money for everyday needs but could not afford to buy a car or real estate, 15\% declared that their financial situation was rather unstable, while more than $12 \%$ declared that could afford anything they wanted whereas more than 19\% refused to reveal their financial situation. Most of the respondents watch TV in order to access the news a few times a week (38\%), 20\% a few times in a month, almost $10 \%$ less than once a month, more than $16 \%$ do it every day and almost $16 \%$ do not watch TV for this purpose. Most of the researched people watch the Vriemia news programme on the Channel One a few times a week (almost 34\%), more than 25\% a few times a month, almost $20 \%$ less than once a month, $12 \%$ every day and $10 \%$ do not watch this programme at all. When asked for their evaluation of the following programmes: Vriemia, Siegodnia, Viesti (programme with a strong influence of the government), Zdies and Sieychas (of niche or even oppositional character), it was evident that Vriemia was rated the highest (6.7 points on a 1-10 scale), the programmes of the Big Three (Vriemia of the Channel One, Siegodnia of the NTV and Viesti of the Rossiya) were rated 5.4 points while oppositional Zdies and Sieychas (on Dozhd channel) 1.2 points. Therefore, it can be stated that the choice of watching Channel
One at least several times a week by $70 \%$ of the surveyed people watching TV reflects viewers' positivity for the content of the programme and confidence as a source of socio-economic and political information. The research results show that the preferred news services are: Vriemia on the Channel One station and Viesti on the Rossiya station. They were positively assessed by $78 \%$ and $72 \%$ of the respondents respectively. These are two of the channels belonging to the Big Three of Russian TV stations. There were noted no statistically important differences between the opinions of the respondents from Moscow and Saint Petersburg.

The respondents were also asked to give their opinions on the Vriemia news programme. 48\% stated that it clearly and objectively presents information about current events, $27 \%$ indicated that Vriemia presents only those opinions which are favourable for the government and that it distorts reality, 25\% of the respondents thinks that there is too little information about positive changes in socio-political life in other countries, while almost 15\% think that Vriemia provides all necessary information to create an objective picture of a given event. The research results show that the viewers believe that the predominant feature of the programme's message is objectivity - such an opinion was expressed by almost $50 \%$ of respondents. It is surprising that educated people have so much confidence in television broadcasting. After all, every third respondent said that only opinions favourable to the ruling elite were presented and that reality was distorted. This implies that a certain number of viewers are critical of the station's message. However, at the same time, only $40 \%$ of these people said that they did not like Vriemia and 25\% said they liked it very much. This reveals that a critical approach to the broadcast of a station and liking it or not do not depend on each other. The station is accepted by the majority of people who are critical of its message, which means that despite the awareness of the use of manipulative techniques, viewers remain faithful to the station and still like it, or even approve of this (distorted) type of message.

Vriemia is perceived as interesting by more than $38 \%$ of the respondents, average by $37 \%$, boring by $30 \%$ and dynamic by $19 \%$. More than one third of the respondents see Vriemia as a programme that 
can be an educational one, but also one third consider that Vriemia promotes one-sided and biased thinking. 26\% state that Vriemia is appropriate for the whole family and only $10 \%$ think that it should not be watched by minors and the overly sensitive to violence. The next stage of the research was to explain what emotions the viewer feels while watching the programme, which turned out to be the most difficult for the respondents. Over 30\% of them could not answer this question. Among the rest, the emotion that was most often indicated while watching Vriemia was indignation (over 34\%) while more than $22 \%$ felt proud of their country. This reflects a noticeable tendency in the programme's message aimed at strengthening the patriotic attitude of Russians, manifested in more frequent communication about the achievements of the country (especially military), emphasizing the role of the Russian nation in history, as well as in creating and maintaining the cult of the Great Patriotic War, (which has resulted in the creation of numerous films, the undertaking of a range of social actions and the creation of associated symbols). Additionally, almost 16\% felt hatred towards other people and $15 \%$ felt fear or unpleasantness while watching Vriemia.

The analysis of the research results shows that the programme is very good at evoking various emotions in viewers; which is what modern media coverage is based on. These emotions are extreme and in the case of Vriemia, apart from those already mentioned, the negative emotions (indignation, hatred, fear, unpleasantness and urge to cry) prevail ( $72 \%$ in total) in relation to the positive (pride in the country, laughter, cheerfulness) ones ( $40 \%$ in total). Nearly $20 \%$ of respondents could not accurately identify the emotions they felt but stated that the emotions evoked by Vriemia swayed them to watch this news programme over other similar programmes. Indignation and unpleasantness while watching Vriemia can be caused both by the form and content of the programme, whereas, laughter, fear, pride, urge to cry, and hatred may arise as a result of the viewer's confrontation with the content of the programme, and then its form will no longer play such a significant role. This shows that most of the emotions felt while watching the programme belong to the sentiments related to its content (almost 80\%). Knowing that the station's message is directed at arousing appropriate (from the government's point of view) emotions and that many techniques are used to achieve this goal, it can be concluded that nearly $70 \%$ of respondents (i.e., people who were able to determine the type of emotions accompanying them) are subject to message manipulation. This means that manipulative techniques aimed at controlling the emotional state of the recipient of the message are quite effective, especially when it comes to arousing a sense of pride in one's own country, as well as outrage and hatred. This result is concerning as the conscious indoctrination of viewers may lead to negative reactions towards representatives of other countries. It also promotes hostility towards supposed enemies, which, according to the assumptions of the message, are for example, the United States, the European Union and the Ukrainian government.

The feeling of outrage or hatred is contrasted with engendering pride in one's own nation (the granfalloon technique), which further distances manipulated people from an objective perception of international relations. We may suspect that the $32 \%$ of people who did not answer this question (they could not or did not want to define their emotions) feel that they can be manipulated, and this fact arouses defensive emotions in them (i.e., a reluctance to describe them or inability to identify them).

\section{Research Results - Discussion}

The analysis of the research (search for statistically important interdependencies) is divided into three general parts. The first one is related to the relationship between the group's characteristics (age, sex, education, financial situation) and the attitudes of the respondents. The second part is devoted to the interdependencies between the frequency of watching TV - specifically the Vriemia news granfalloon - and the attitudes and opinions of the respondents. The final part was based on the interdependencies between different opinions and attitudes.

The analysis of the research results (Pearson's chisquared test for independence and student's t-test) showed no statistically important differences between men and women with reference to frequency of watching television in general (although slightly more men than women watch TV every day and 
slightly more women do not watch Vriemia programme at all). Based on the independence test and the likelihood-ratio test, only women were undecided as far as the opinions on Vriemia's characteristics. Moreover, surprisingly, more men than women declared that Vriemia presents too much violence $(16 \%$ to $4 \%$ ), and that Russia is compared to other countries all the time (28\% to $10 \%)$. Similarly, more men than women felt hatred while watching Vriemia (27\% to $8 \%)$. As far as age and education are concerned, unfortunately, no relationship could be revealed as the group was too homogenous with respect to these two variables. With reference to the financial situation, based on ANOVA and the likelihood-ratio test it appeared that respondents' attitudes are generally not dependent on their financial situation. The only relationship was found in the case of the opinion that Vriemia is a programme for the whole family which was confirmed mostly by people with a very high economic position (53\% compared to $35 \%$ of people with the very difficult economic situation and $18 \%$ of the respondents with an average financial situation). The analysis of the research results shows that, in general, the customs and opinions of the respondents do not depend on any of the basic sociological variables like gender, age, education or financial situation. Differences were expected to emerge with respect to gender (women were expected to be more vulnerable to violence and emotions), education (the more educated people are, the lesser the likelihood of vulnerability to manipulation techniques and the greater opportunity to develop independent thinking) and financial situation (economically better off people were expected to be less exposed to propaganda due to the ability to travel and see the world outside Russia, meet with people with different viewpoints and greater access to international and independent media). Nevertheless, no such relations were found.

Gabriel's post-hoc test showed the dependency between the evaluation of the Big Three news programmes and the frequency of watching TV. People who watched the news on other platforms than TV media gave the lowest evaluation of the programmes (the average hardly reached 4 points on a 1-10 scale) while respondents watching TV every day or a few times a week in order to obtain information rated the three news programmes the highest ( 6 points on the same scale). People who do not watch TV did not share the opinion that Vriemia is a programme for the whole family, while people watching TV frequently were of this opinion (35\%). Similarly, people who watched TV less frequently stated that watching Vriemia was not pleasant (over 22\%), whereas this opinion was absent among those respondents who watched TV every day or a few times a week. Analogously, respondents who watch TV more frequently, characterised Vriemia as interesting (almost 70\%) and dynamic (30\%), while people are watching Vriemia only occasionally described it as monotonous and boring (38\%) as well as average (56\%). The likelihoodratio test showed that people watching Vriemia every day or very frequently were far less objective towards their favourite news programme: $63 \%$ of the respondents stated that Vriemia consistently and objectively presents current events, over $31 \%$ thinks that it provides all necessary information to create an objective picture of a given event, while people who watch Vriemia occasionally think that Vriemia presents only those opinions which are favourable for the government (35\%) and that it could present more information about important problems for Russian society (60\%). Those respondents who watch Vriemia every day think that it is a programme for the whole family (50\%) and that it has an educational value (almost $20 \%$ ), while people are watching Vriemia occasionally are of the opposite opinion, and they also believe that Vriemia is not an appropriate programme for people of a sensitive disposition as it presents too much violence. It is clearly noticeable that people watching TV, and especially Vriemia, very often lose objectivity and are more vulnerable to manipulation and adopt the opinions desired by the government. Propaganda has fulfilled its role. The research also revealed an interrelation between the frequency of watching Vriemia news and the person's pride in their country. The more frequently people watch Vriemia, the prouder of their country they feel: $44 \%$ among people who watch it every day, over $31 \%$ among respondents watching it a few times a week and less than 9\% among people watching it a few times a month. It also verifies the hypothesis regarding the power of Russian propaganda delivered through mass media, especially by television. Vriemia is constructed in such a way as to show a clear line between we (Russia) and them (generally, 
the rest of the world). It is expected to deliver news favourable to the government while discrediting adversaries (which are generally the US and the West) on the one hand and to glorify the deeds of the country in order to evoke pride and a sense of being a chosen (exceptional) nation on the other. This, in turn, induces hatred towards other nations (or at least a sense of superiority), who are shown as worse, hostile or critical of Russia out of jealousy. Consequently, people watching Vriemia frequently are vulnerable to such propaganda and adopt the same worldview, one which is favourable to the government. Hence, manipulation of the society in such circumstances (inability or lack of desire for objective evaluation of the programme's content) is much easier.

The likelihood-ratio test revealed interdependencies between certain opinions, beliefs, and attitudes of the respondents. Those respondents who consider Vriemia an appropriate programme for children never indicated that this programme distorts the presented reality and that positive changes in socio-political life in other countries are too rarely mentioned, while almost $30 \%$ of people with an opposing viewpoint on the programme's suitability for children confirmed the two above-mentioned opinions. Similarly, respondents who believe that Vriemia is a programme for the whole family far more frequently (over $74 \%$ compared to $38 \%$ of the respondents of an opposite opinion) confirmed that it consistently and objectively presents current events and that it provides all necessary information to build an objective picture of said events (over $34 \%$ compared to only $7 \%$ of respondents with an opposite opinion). Moreover, respondents who perceive Vriemia as an educational programme (Figure 1) also far more frequently than those of the opposite opinion pointed out that while presenting the news on Vriemia, Russia is compared to other countries all the time (almost 66\%), it consistently and objectively presents current events (over $74 \%$ ), it provides all necessary information to build an objective picture of events (almost 38\%) and that well-known politicians appear too rarely (23\%). Those who think that Vriemia does not fulfil an educational function more frequently declared that the programme distorts the presented reality (33\%) and shows too much violence (over 13\%). Finally, those respondents who

\section{Figure 1}

Relationship Between the Respondents' Opinions on Vriemia with the Statement that the Programme has an Educational Function

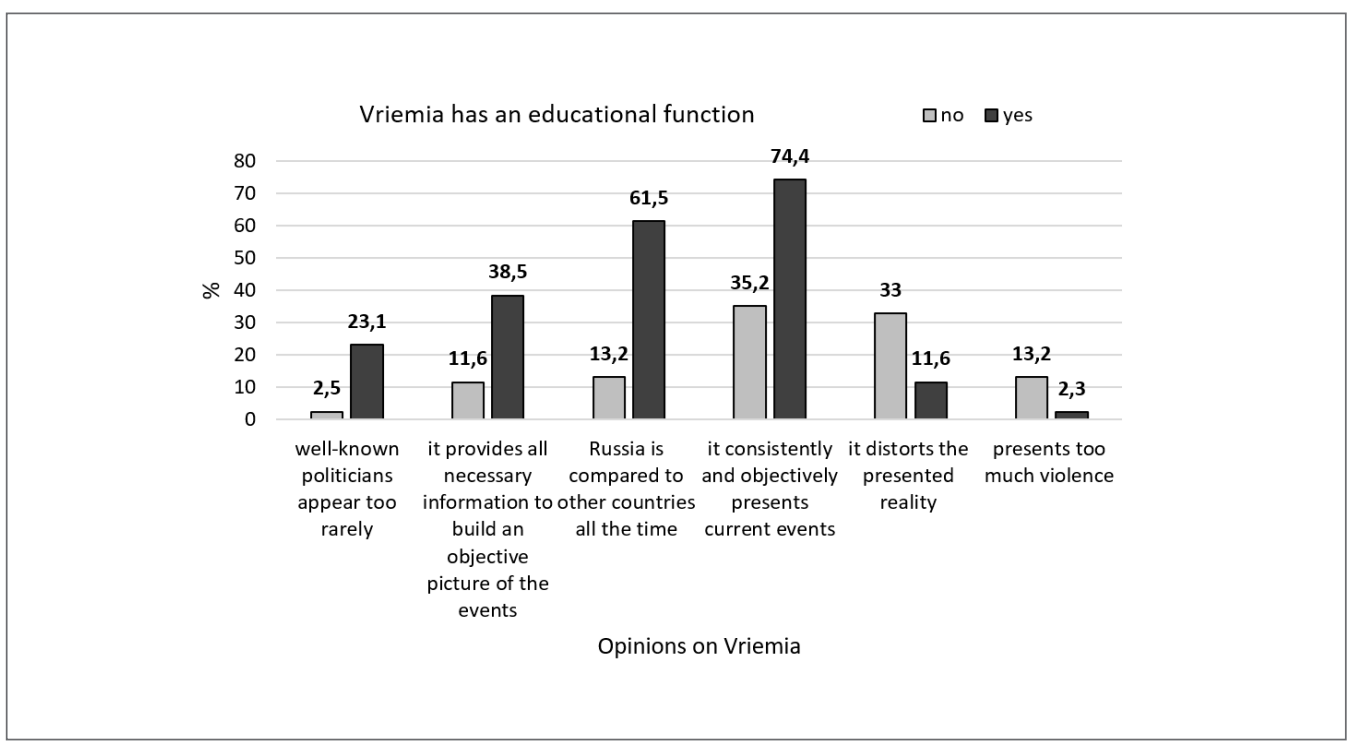




\section{Figure 2}

Relationship Between the Respondents' Opinions of Vriemia with the Statement that the Programme Promotes One-sided and Biased Thinking.

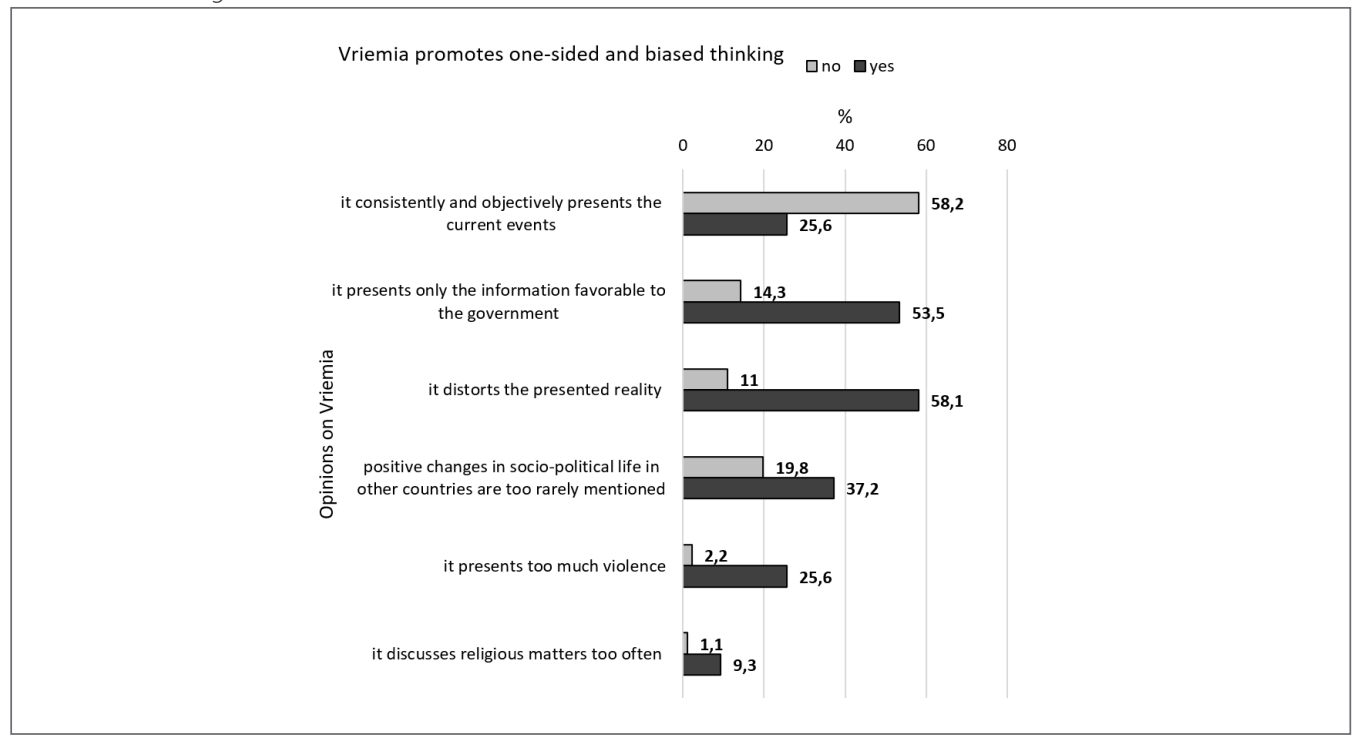

believe that Vriemia promotes one-sided and biased thinking (Figure 2) more frequently state that it presents only the information favourable to the government (almost 54\%), distorts the presented reality (58\%), positive changes in socio-political life in other countries are too rarely mentioned (over $37 \%$ ), presents too much violence (almost 26\%) and discusses religious matters too often (over 9\%), whereas other respondents believe that Vriemia consistently and objectively presents the current events (over 58\%).

Propaganda remains the main tool of information warfare in Russia (nothing has changed since the Cold War). The message is dominated by the bias and partiality of messages, a simplified image, presented in black and white, with an obvious message, evaluation, and commentary, aimed at unconditional orientation of the recipient's emotions, and thus, his or her opinions and attitudes. In the linguistic sphere, there is visible rhetoric subordinated to discrediting the opponent, which is characterized by the language of emotions, comparisons, and evaluations, in which facts are of secondary importance. Moreover, the propaganda refers to the senti- ments of Russians, their eternal fears, and imperial dreams as well as legends about an exceptional or even chosen nation to guard certain values against the invasion of Western liberal culture, which is programmed to destroy what is Russian.

\section{Conclusions}

The mainstay of information operations in Russia is propaganda. It aims to implement social control, and the basic tool, as in the Cold War era, is special propaganda. In order to achieve the goals of information mobilization by the Russian media, numerous techniques of manipulation are used. These include the manipulation of emotions, images, and sounds, as well as media political discourse. The Russian authorities can easily introduce propaganda messages into public circulation, as most media remain under the control and influence of the state. Therefore, everything that is broadcast serves the information strategy, and even if the message seems chaotic and incoherent at first glance, it only means that it has a specific task to fulfil (introducing information chaos and causing irritation among the recipients). It is also 
largely based on stereotypes built on preserved historical memory and myths, historical and cultural heritage, and the need to defend Orthodox values and the resulting belief in the spiritual uniqueness of Russia and Russians.

The research indicated that Russian propaganda still has a huge impact on society, its way of thinking and thus the support they present for the government. These outcomes are in-line with the conclusions drawn by other researchers already quoted in this paper. Creatively commercialized narratives produced by the media supporting the Russian government are still winning the information war. The final research findings clearly show that people who are able to objectively assess Vriemia's content are definitely more critical towards what the programme offers. They are not easily manipulated, and they preserve their own opinions. People who succumbed to propaganda are eager to allow children to watch Vriemia, perceiving it as a programme having an educational function without recognising it as a threat for young minds by limiting independent thinking. The research results allowed verification of the initial hypotheses. The study confirmed that Russian political marketing uses various techniques which are an important part of the media coverage, and consequently, it is able to manipulate the audience's opinions and attitudes. However, the results did not entirely justify the assumption that the more educated and better financially situated the respondents are, the more objective their perception of a programme's contents. It appeared that education and better financial situation do not necessarily mean the ability to assess the media coverage objectively or critically and do not result in lesser vulnerability to manipulation. Nevertheless, the research verified positively the existence of the interdependence between the frequency of watching TV, Vriemia in particular, and vulnerability to manipulation and the ability to objectively assess the programme's content. In conclusion, the research results evidently indicate the interdependence between the favourable opinions about Vriemia's contents and vulnerability to manipulation and propaganda techniques.

\section{References}

Andriukaitis, L. (2020). Russian propaganda efforts in the Baltics and the wider region. Vilnius Institute for Policy Analysis, 1-16. https://vilniusinstitute. lt/wp-content/uploads/2020/05/VIPA_Andriukaitis_2020_Iv4-1\%D0\%B5.pdf

Antczak, A., Plashkina, I. (2017). Kultowa propaganda. Rosyjski dyskurs komunikowania politycznego w przekazie telewizyjnym stacji Pierwyj Kanat [The cult propaganda: Russian political discourse based on Channel One television broadcast]. Adam Marszałek.

Averin, A., (2018). Russia and its many truths. In: J. Althuis. L. Haiden (eds.), Fake News. A Road Map (pp. 59-67). NATO Strategic Communication Centre of Excellence and King's Centre for Strategic Communication.

Bayer, J., Bitiukova, N., Bard, P., Szakács, J., Alemanno, A., \& Uszkiewicz, E. (2021). Disinformation and propaganda: impact on the functioning of the rule of law and democratic processes in the EU and its Member States: 2021 update. Brussels: European Parliament, Policy Department for External Relations. https://www.sipotra.it/wp-content/ uploads/2021/05/Disinformation-and-propaganda-impact-on-the-functioning-of-the-rule-oflaw-and-democratic-processes-in-the-EU-andits-Member-States-2021-update.pdf

Berzina, I. (2018). Political trust and Russian media in Latvia. Journal on Baltic Security, 4(2).

Boleckaya, K., \& Sagdiyev, R. (2010). Первым каналом» владеет однокурсница Путина и подруга Абрамовича, Ведомости, http://www. vedomosti.ru/library/articles/2010/11/01/sekrety_pervoj_knopki

Bradshaw, S., \& Howard, P. N., (2019). The Global Disinformation Order 2019 Global Inventory of Organised Social Media Manipulation. University of Oxford.

Dimock, M. (2019). Defining generations: Where Millennials end and Generation Z begins. Pew Research Center, 17(1), 1-7. https://www.pewresearch.org/fact-tank/2019/01/17/where-millennials-end-and-generation-z-begins/

Glebko, A. (2013). Смотрите, слушайте и читайте: говорят, показывают и пишут путин, ковальчук, миллер, потанин и усманов, или кому принадлежат российские телеканалы и крупнейшие газеты [Watch, listen, and read: what Putin, Kovalchuk, Miller, Potanin, and Usmanov say, show, and write, or who owns 
Russian TV channels and major newspapers], Экономическая и философская газета. http:// www.eifgaz.ru/appg-2-13.htm

Helmus, T. C., Bodine-Baron, E., Radin, A., Magnuson, M., Mendelsohn, J., Marcellino, W., Bega, A. \& Winkelman, Z. (2018). Russian Social Media Influence: Understanding Russian Propaganda in Eastern Europe. RAND Corporation.

Karlsen, G. H. (2019). Divide and rule: ten lessons about Russian political influence activities in Europe. Palgrave Communications, 5(1), 1-14. https://doi.org/10.1057/s41599-019-0227-8

Kent, T. (2020). Striking back. Overt and covert options to combat Russian disinformation. The Jamestown Foundation.

Kovaleva, N. (2018). Russian information space, Russian scholarship, and Kremlin controls. Defence Strategic Communications, 4(4), 133-171. https:// www.ceeol.com/search/article-detail?id=775394

Kuzichkin, A., \& Hanley, M. (2021). Russian Media Landscape. Structures, Mechanisms, and Technologies of Information Operations. The NATO Strategic Communication Centre of Excellence.

Lukyanova, I. (2001, July 30). Если вы уже устали. Профиль, https://profile.ru/archive/esli-vy-uzheu-stali-106189/

Łabuszewska, A. (2015). Cień Tambowa, 17 mgnień Rosji [Tambov's Shadow, 17 glimpses into Russia]. Tygodnik Powszechny. http://labuszewska. blog.tygodnikpowszechny.pl/tag/kooperatywa-oziero/

Mölder, H., Sazonov, V., Chochia, A., \& Kerikmäe, T. (2021). The Russian Federation in Global Knowledge Warfare. In H. Mölder, V. Sazonov, A. Chochia, T. Kerikmäe (Eds.), Influence Operations in Europe and Its Neighbourhood. Springer Nature Switzerland AG.

The Economist. (2017, January 21). Putin's prevaricating puppets. RT's propaganda is far less influential than Westerners fear. https://www.economist. com/europe/2017/01/19/rts-propaganda-is-farless-influential-than-westerners-fear

Ramsay, G., \& Robertshaw, S. (2019). Weaponising news RT, Sputnik and targeted disinformation. King's College London.

Rogers, R., \& Niederer, S. (2020). The Politics of Social Media Manipulation. Amsterdam: Amsterdam University Press.

Shcherakova, A. (2005, March 1). Интервью: Михаил Клишин, гендиректор банка "Россия" [Interview: Mikhail Klishin, director general of Bank Rossiya]. Ведомости 2005, http://www. vedomosti.ru/newspaper/articles/2005/03/01/intervyu-mihail-klishin-gendirektor-banka-rossiya

Sobolev, S. (2016, April 10). Убыток «Первого канала» от основной деятельности приблизился к 10 млрд руб [Channel One's losses incurred are close to 10 billion rubles]. AdIndex.ru, http://adindex. ru/news/media/2016/04/10/133038.phtml

Strovsky, D., \& Schleifer, R. (2020). The Russian media as a promoter of manipulative approaches: The case of the Syrian Civil War. The Journal of the Middle East and Africa, 11(1), 1-24. https:// doi.org/10.1080/21520844.2019.1692609

Vartanova, E. L., (2013). Телевидение в России. Состояние, тенденции и перспективы развития [Television in Russia. State, Trends and Development Prospects]. Федеральное агентство по печати и массовым коммуникациям. https:// istina.msu.ru/reports/3502187/.

Vartanova, E. L., (2017). Телевидение в России в 2016 году. Состояние, тенденции и перспективь развития. [Television in Russia. State, Trends and Development Prospects]. Федеральное агенство по печати и массовым коммуникациям. https:// istina.msu.ru/reports/66340750/ 